Article

\title{
Greenhouse Gas Emissions from Cultivation of Plants Used for Biofuel Production in Poland
}

\author{
Paweł Wiśniewski * (D) and Mariusz Kistowski \\ Department of Landscape Research and Environmental Management, Faculty of Oceanography and Geography, \\ University of Gdansk, Bażyńskiego 4, 80309 Gdańsk, Poland; mariusz.kistowski@ug.edu.pl \\ * Correspondence: pawel.wisniewski@ug.edu.pl
}

Received: 29 February 2020; Accepted: 14 April 2020; Published: 16 April 2020

\begin{abstract}
A reduction of greenhouse gas (GHG) emissions as well as an increase in the share of renewable energy are the main objectives of EU energy policy. In Poland, biofuels play an important role in the structure of obtaining energy from renewable sources. In the case of biofuels obtained from agricultural raw materials, one of the significant components of emissions generated in their full life cycle is emissions from the cultivation stage. The aim of the study is to estimate and recognize the structure of GHG emission from biomass production in selected farms in Poland. For this purpose, the methodology that was recommended by the Polish certification system of sustainable biofuels and bioliquids production, as approved by the European Commission, was used. The calculated emission values vary between $41.5 \mathrm{~kg} \mathrm{CO} 2 \mathrm{eq} / \mathrm{t}$ and $147.2 \mathrm{~kg} \mathrm{CO} \mathrm{eq}_{2} \mathrm{t}$ dry matter. The highest average emissions were obtained for wheat $(103.6 \mathrm{~kg} \mathrm{CO} 2 \mathrm{eq} / \mathrm{t})$, followed by maize $\left(100.5 \mathrm{~kg} \mathrm{CO}_{2} \mathrm{eq} / \mathrm{t}\right)$, triticale $(95.4 \mathrm{~kg}$ $\left.\mathrm{CO}_{2} \mathrm{eq} / \mathrm{t}\right)$, and rye $(72.5 \mathrm{~kg} \mathrm{CO} 2 \mathrm{eq} / \mathrm{t})$. The greatest impact on the total GHG emissions from biomass production is caused by field emissions of nitrous oxide and emissions from the production and transport of fertilizers and agrochemicals. Emissions that were generated at the stage of production, storage, and transport of seeds and during the use of fuels in agricultural and forestry machinery have a significantly smaller share in the total GHG emissions from biomass production.
\end{abstract}

Keywords: greenhouse gases; emission; biofuels; biomass; cultivation; plants; Poland

\section{Introduction}

Using renewable energy sources (RES) is one of the crucial components of the sustainable development, giving rational economic, ecological, and social effects. Developed countries notice the necessity of emission reduction from combustion of energy fuels processes and the necessity of seeking alternative energy resources. Support for development of the use of renewable energy sources became a very important objective within the European Union (EU) [1]. The share of energy from renewable sources in the EU, in gross final consumption of energy by 2030, should be at least $32 \%$, according to the Directive of the European Parliament and of the Council of 11 December 2018 on the promotion of the use of energy from renewable sources [2]. The directive defines, among other things, the criteria of sustainable development and reduction of greenhouse gas (GHG) emission in relation to biofuels, bioliquids, and fuels from biomass. According to its assumptions, this limitation should be at least $50 \%$ in relation to the fossil equivalent in the case of biofuels and biogas used in the transport sector and bioliquids produced in installations that were put into operation on 5 October 2015 or earlier, and at least $60 \%$ in the case of biofuels and biogas used in the transport sector and bioliquids produced in installations that were put into operation from 6 October 2015 to 31 December 2020. This is expected to increase to $65 \%$ from the 1st January 2021 and from 2026 to $70 \%$. The national target for Poland, as set out in Annex I of the aforementioned Directive, assumes the achievement of $15 \%$ share of energy from renewable sources in gross final energy consumption in the year 2020. Based on the data of the Central 
Statistical Office [3], the share of energy from renewable sources in the total primary energy acquisition in Poland in 2018 amounted to $14.3 \%$ (as compared to $29.9 \%$ in EU-28), which gives an increase of $2.2 \%$ when compared to 2014 (in EU-28 there was a 3.8\% increase during the same period).

Biofuels and biogas play an important role in the structure of energy generation from renewable sources in Poland [4]. Solid biofuels (mainly agricultural biomass, firewood, and waste from forestry) are the main carrier of renewable energy - their share in obtaining energy from RES in Poland is $69.3 \%$. However, it is worth noting that this share has been systematically decreasing in the period of 2011-2017. An increase, in this regard, took place in the wind power sector and in the production of liquid biofuels. From liquid biofuels, $10.2 \%$ of energy is obtained from renewable sources, while, from biogas-3.3\% [3,5]. Therefore, green technologies in the Polish energy sector are primarily based on biomass, and full use of its energy potential might be ensured by reaching the National Indicative Target and the fulfilment of EU legal obligations for 2020 [6-8]. Biomass for energy has a key role within the EU policy support for RES, in which targets are the main drivers, together with overarching biomass guidelines to anticipate any environmental constraints [9]. However, it is necessary to know the GHG emission generated in their full life cycle, including those related to cultivation of raw materials, in order to assess the fulfilment of the criterion concerning the GHG emission reduction capacity in relation to biofuels, bioliquids and fuels from biomass. The aim of the study is to estimate GHG emission that are caused by the cultivation of selected plants (winter wheat, triticale, winter rye, and maize), used for biofuel production in Poland, as well as to recognize the structure of emission from biomass production. The basis for the study was the assumption that emissions from the cultivation of raw materials are an important source of total GHG emissions in a biofuels life cycle. An important assumption was also to check the possibility of using the Global Nitrous Oxide Calculator (GNOC) to estimate the field emissions of nitrous oxide.

\section{Materials and Methods}

Questionnaires that were provided by agricultural producers of raw materials for biofuel production were the source material for the research. The questionnaires were sent to 15 agricultural producers of biofuels in the north-western part of Poland. All of them were responded and provided information on the size of the farm, crop area, fuel consumed, seed used, yield, mineral, and organic fertilizers and pesticides used (their dose, type, and composition).

\subsection{Location and Characteristics of the Studied Farms}

The studied farms are located in the north-western and western part of Poland, in West Pomeranian Voivodeship (12 locations) and Lubusz Voivodeship (three locations), respectively (Table 1, Figure 1). All of the farms are located in the lowland area of Poland, at altitudes not exceeding $100 \mathrm{~m}$ above sea level, with the exception of two farms in the central and southern part of the Lubusz Voivodeship-located 150-200 m above sea level. The studied farms are characterized by different natural conditions for agricultural production. The last glacial (Vistulian) and postglacial processes form the landscape of these areas. The study area is located in temperate warm transitional climate zone. Its territory is affected by air masses from both the Atlantic Ocean and the continental Eurasian landmass. Concerning the transfer of air masses, westerly winds are the most prevailing ones in the study area. On average, annual totals of precipitation are ca. 550-600 $\mathrm{mm}$. The number of days with precipitation $(\mathrm{RR}>0.1 \mathrm{~mm})$ is approximately 160 per year [10]. Brunic Arenosols, Haplic Luvisols, and Podzols dominate the soil cover of the studied area. The Fluvisols occur in river valleys [11]. 
Table 1. Location and area of study farms.

\begin{tabular}{ccccc}
\hline No. of Farms & Place & Farm Area (Hectares) & Voivodeship & District \\
\hline 1 & Banie & 900 & West Pomeranian & Gryfice \\
\hline 2 & Świerzno & 100 & West Pomeranian & Kamień Pomorski \\
\hline 3 & Gryfice Zdrój & 300 & West Pomeranian & Gryfice \\
\hline 4 & Trzebiatów & 60 & West Pomeranian & Gryfice \\
\hline 5 & Kicko & 120 & West Pomeranian & Stargard \\
\hline 6 & Lusowo & 65 & West Pomeranian & Gryfice \\
\hline 7 & Chojna & 700 & West Pomeranian & Gryfino \\
\hline 8 & Płoty & 180 & West Pomeranian & Gryfice \\
\hline 9 & Gryfice & 165 & West Pomeranian & Gryfice \\
\hline 10 & Gościejewo & 142.5 & West Pomeranian & Gryfice \\
\hline 11 & Swobnica & 121 & West Pomeranian & Gryfino \\
\hline 12 & Godków & West Pomeranian & Gryfino \\
\hline 13 & Mycielin & 250 & Lubusz & Żagań \\
\hline 14 & Brzozowa & 68.5 & Lubusz & Sulęcin \\
\hline 15 & Świebodzin & 520 & Lubusz & Świebodzin \\
\hline
\end{tabular}

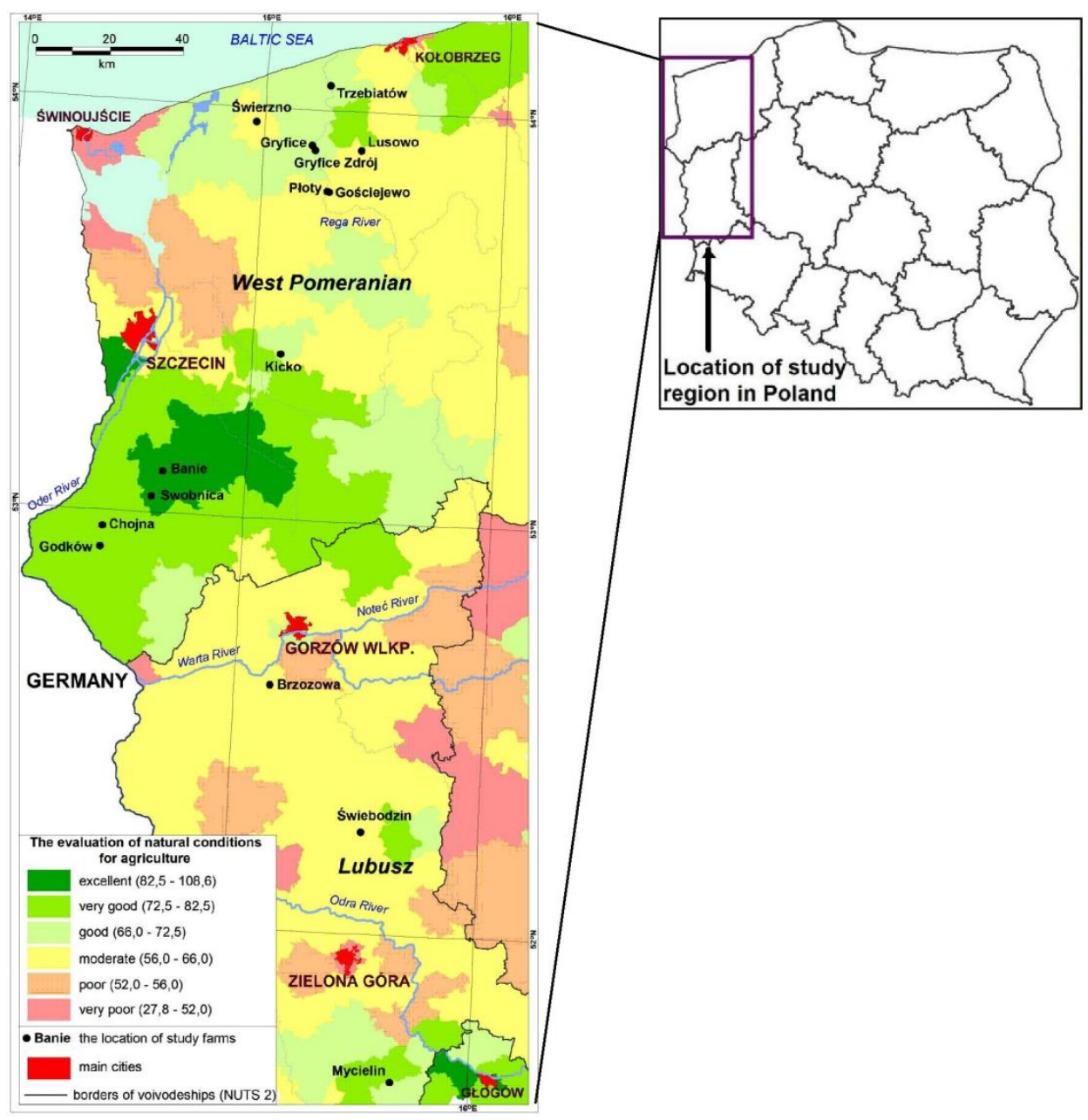

Figure 1. Location of study farms against the background of agricultural production space (Source: Authors based on $[12,13])$. 
On the basis of the analysis of the spatial distribution of the index of agricultural valorisation of production space in Poland, taking soil quality, agroclimate, relief, and water conditions into account [12,13], it was found that the farms in Banie and Swobnica have excellent conditions (Figure 1). The decisive factor is constituted by soils, partially included in the so-called Pyrzyce black earths, which are among the most fertile in Poland [14,15]. The other two farms in the Gryfino district are characterized by very good conditions. The remaining farms in the West Pomeranian Voivodeship have half as good and moderate conditions for cultivation, whereas, in the Lubusz Voivodeship: Mycielin has good conditions and the other two are moderate. The studied fields were not irrigated.

The 15 farms under analysis cover a total area of 4042 ha (Table 1). Their acreage is highly diversified, from 60 to 900 ha. They can be divided into four surface categories. The four smallest ones (up to $100 \mathrm{ha}$ ) are located in the northern part of the area, being closest to the Baltic Sea, and in Brzozowa. The next five, occupying from a 101 to 200 ha each, are located in the area of Gryfice and Płoty as well as in Kicko and Swobnica. Three large farms (250-350 ha each) are located in Zdrój near Gryfice, Godków, and Mycielin. The three with the largest area are located in Świebodzin (520 ha), Chojna (700 ha), and Banie (900 ha)—the last two in the best agro-ecological conditions.

\subsection{The Methodology for Assessment GHG Emissions from Biomass Production}

The estimation of GHG emission caused by the cultivation of raw materials for biofuel production in the above-mentioned farms was made in accordance with the methodology that was recommended by the KZR INiG system [16]. This is the Polish system of certification of sustainable production of biofuels, bioliquids, and raw materials, owned by the Oil and Gas Institute-National Research Institute. The European Commission approved this system in 2014 in relation to proving compliance with the sustainable development criteria, according to the directives of the European Parliament and the EU Council $[17,18]$.

The assessment of the KZR INiG system covers, in terms of compliance with the sustainable development criteria, biomass cultivated and collected in the territory of the European Union, wastes and residues collected in the territory of the EU, as well as raw materials, biofuels, and bioliquids produced in the territory of the European Union. The assessment covers the entire life cycle of biofuels, bioliquids, commencing from the stage of raw material cultivation or waste collection point, to the final stage of consumption of biofuels and bioliquids, formation of wastes and residues, taking into account all intermediate stages (buying, trading, and processing of the biomass). The KZR INiG system also has a clearly set procedure to assess biofuels received in a co-processing process (processing with fossil fuel). The procedure describes the methodology of the calculation of biomass fraction and GHG emission [19]. For the purposes of the article, it was limited to assessing GHG emissions from the cultivation of plants used for biofuel production. Input data (variables) affecting emissions from crops include seeds, fuel, fertilizers, pesticides, yield, and field emission of $\mathrm{N}_{2} \mathrm{O}$. On the basis of questionnaires that were gathered from selected agricultural producers, information was obtained in the area of cultivation, the name and amount of fertilizers used, the name and amount of plant protection products used, the amount of seed, fuel consumption for driving agricultural machinery, and other energy sources used during cultivation in 2019 (Table 2). 
Table 2. Agricultural data based on which components of greenhouse gas (GHG) emissions have been determined.

\begin{tabular}{|c|c|c|c|c|c|c|c|c|c|}
\hline \multirow[t]{2}{*}{ No. of Farms } & \multirow[t]{2}{*}{ Crop } & \multirow{2}{*}{$\begin{array}{l}\text { Seed } \\
(\mathrm{kg} / \mathrm{ha})\end{array}$} & \multirow{2}{*}{$\begin{array}{l}\text { Yield } \\
\text { (t/ha) }\end{array}$} & \multicolumn{4}{|c|}{$\begin{array}{l}\text { Mineral Fertilizers } \\
\text { (kg/ha Pure Nutrient) }\end{array}$} & \multirow[t]{2}{*}{$\begin{array}{l}\text { Pesticides } \\
\text { (kg/ha) }\end{array}$} & \multirow{2}{*}{$\begin{array}{c}\text { Fuel } \\
\text { Consumption } \\
\text { (1/ha) }\end{array}$} \\
\hline & & & & $\mathbf{N}$ & $\mathrm{P}_{2} \mathrm{O}_{5}$ & $\mathbf{K}$ & $\mathrm{CaO}$ & & \\
\hline \multirow{2}{*}{1} & wheat & 117 & 6.8 & 61.1 & 21.2 & 48.0 & 0 & 1.0 & 120 \\
\hline & triticale & 135 & 10.0 & 53.1 & 21.2 & 48.0 & 0 & 1.0 & 85 \\
\hline \multirow{2}{*}{2} & wheat & 180 & 5.8 & 46.0 & 40.0 & 60.0 & 0 & 0.02 & 100 \\
\hline & triticale & 180 & 5.8 & 46.0 & 40.0 & 60.0 & 0 & 0.02 & 100 \\
\hline 3 & maize & 60 & 7.0 & 8.0 & 6.3 & 72.0 & 1000 & 0.2 & 80 \\
\hline 4 & rye & 120 & 4.5 & 23.8 & 6.0 & 12.0 & 0 & 0 & 80 \\
\hline 5 & triticale & 120 & 6.0 & 45.6 & 30.0 & 140.0 & 0 & 0.4 & 80 \\
\hline 6 & triticale & 200 & 6.0 & 51.7 & 20.0 & 30.0 & 33.4 & 1.1 & 85 \\
\hline \multirow{3}{*}{7} & wheat & 160 & 7.0 & 53.8 & 6.0 & 25.0 & 333.3 & 0.2 & 105 \\
\hline & triticale & 150 & 5.5 & 46.6 & 0 & 0 & 222 & 0.2 & 105 \\
\hline & maize & 20 & 9.0 & 46.2 & 13.8 & 24.0 & 333.3 & 0.1 & 105 \\
\hline 8 & rye & 180 & 5.0 & 30.1 & 2.4 & 3.6 & 500 & 1.2 & 100 \\
\hline 9 & triticale & 200 & 4.5 & 30.1 & 2.4 & 3.6 & 500 & 1.2 & 100 \\
\hline 10 & triticale & 160 & 5.0 & 26.0 & 14.4 & 14.4 & 0 & 0 & 105 \\
\hline 11 & triticale & 165 & 7.2 & 28.8 & 13.8 & 26.4 & 387.5 & 1.0 & 87 \\
\hline 12 & triticale & 110 & 6.0 & 39.2 & 0 & 40.0 & 750 & 0.4 & 110 \\
\hline \multirow{2}{*}{13} & wheat & 140 & 8.0 & 41.9 & 21.2 & 4.0 & 0 & 0.8 & 140 \\
\hline & triticale & 150 & 6.0 & 39.1 & 21.2 & 40.0 & 0 & 0.8 & 80 \\
\hline 14 & rye & 150 & 5.0 & 0 & 0 & 0 & 0 & 0.2 & 85 \\
\hline 15 & maize & 20 & 5.0 & 57.6 & 32.0 & 48.0 & 0 & 0.06 & 85 \\
\hline
\end{tabular}

(Source: Authors based on surveys of agricultural producers).

The greenhouse gas emissions from biomass production were calculated according to the following formula:

$$
\mathrm{e}_{\mathrm{ec}}=\mathrm{e}_{\text {seed }}+\mathrm{e}_{\mathrm{chem}}+\mathrm{e}_{\mathrm{irr}}+\mathrm{e}_{\text {field }}+\mathrm{e}_{\mathrm{burn}}+\mathrm{e}_{\mathrm{mm}}
$$

where: $e_{\mathrm{ec}}-\mathrm{GHG}$ emissions from biomass production; $\mathrm{e}_{\text {seed }}$-emissions from the use of grain for sowing; $e_{c h e m}$-emissions from the production and transport of fertilizers and agrochemicals; $\mathrm{e}_{\text {irr }}$-emissions from irrigation; $\mathrm{e}_{\text {field }}$-emissions from soil cultivation (field emissions); $\mathrm{e}_{\text {burn }}$ - emissions from burning of ground before and after cultivation; and, $\mathrm{e}_{\mathrm{mm}}$-emissions from agricultural and forestry machinery and other mobile or stationary equipment.

The GHG emission from biomass production $\left(\mathrm{e}_{\mathrm{ec}}\right)$ was expressed in carbon dioxide equivalent $\left(\mathrm{CO}_{2} \mathrm{eq}\right)$ per dry matter unit $\left[\mathrm{kg} \mathrm{CO} \mathrm{CO}_{2} \mathrm{eq} / \mathrm{t}\right]$, adopting the global warming potential (GWP) for $\mathrm{N}_{2} \mathrm{O}=265$, according to the value that was indicated in the IPCC Fifth Assessment Report [20]. The GHG emission from seeds used for sowing $\left(\mathrm{e}_{\text {seed }}\right)$ includes the emission that is generated during the production, storage, and transport of seeds. Where the seed was self-produced, the amount of biomass retained as seed was deducted from the total biomass production in order to calculate the net biomass production. The standard coefficients of GHG emission from seeds used for sowing were applied according to the BioGrace calculator (v. 4d), as recommended by the European Commission [21]. The GHG emission from the production and transport of fertilizers and plant protection products $\left(\mathrm{e}_{\mathrm{chem}}\right)$ was calculated according to a formula:

$$
\mathrm{e}_{\text {chem }}=\mathrm{Q}_{\text {chem }} \times \mathrm{F}_{\text {chem }}
$$

The amount of fertilizers or plant protection products $\left(\mathrm{Q}_{\mathrm{chem}}\right)$ applied per unit area of land (ha) is expressed in mass unit $(\mathrm{kg})$ of the pure component-nitrogen, phosphorus, potassium, or active substance of the plant protection product. The GHG emission factor from the production and transport of mineral fertilizers or plant protection products $\left(\mathrm{F}_{\text {chem }}\right)$ is expressed in $\mathrm{CO}_{2}$ equivalent per unit mass 
of fertilizer or plant protection product. The emission factors were applied according to the BioGrace calculator (v. 4d) [21].

The GHG emissions from field irrigation $\left(\mathrm{e}_{\mathrm{irr}}\right)$ are those that result from the use of equipment for pumping, storing, and distributing water. The associated GHG emissions are calculated as $\mathrm{e}_{\mathrm{mm}}$ emissions. The studied fields were not irrigated; hence, GHG emissions from crop irrigation are zero.

The GNOC (Global Nitrous Oxide Calculator) recommended by the European Commission was used in order to calculate the field emission of nitrous oxide ( $\left.e_{\text {field }}\right)$ [22]. In accordance with the Communication of the European Commission [23] as well as the guidelines of the KZR INiG [16], the IPCC methodology, including both direct and indirect emissions, can be applied when taking the $\mathrm{N}_{2} \mathrm{O}$ emission from soils into account. All three levels are allowed-from the basic and commonly used Tier 1 level, not even based on national data, to the most detailed Tier 3 level. The GNOC calculator used in this work allows for estimating the amount of field emission at Tier 2 level. Tier 2 methodologies require data that are both detailed and respect the relationships between emission sources. These data can only be collected by sampling at the farm scale [24]. The GNOC tool was developed based production data from the Food and Agriculture Organization of the United Nations (FAO) database and the input data that are necessary for performing the calculations include, among others, the place of cultivation, grain and straw yields, soil conditions, information on irrigation, the dose of applied fertilizers, information on post-harvest residues, as well as basic environmental parameters $[25,26]$. This tool calculates $\mathrm{N}_{2} \mathrm{O}$ emissions that are based on the approach of Stehfest and Bouwman [27]. It uses an exponential algorithm that considers site and management specific characteristics, such as soil texture, climate, soil organic matter, $\mathrm{pH}$, and vegetation [28,29].

The combustion of plants, dead organic matter, and post-harvest residues might cause the emission of $\mathrm{CH}_{4}$ and $\mathrm{N}_{2} \mathrm{O}$ due to incomplete combustion. The $\mathrm{CO}_{2}$ emission from biomass combustion ( $\left.\mathrm{e}_{\text {burn }}\right)$ is considered to be zero [30,31]. The emission from the use of fuels in agricultural and forestry machines $\left(\mathrm{e}_{\mathrm{mm}}\right)$, expressed in $\mathrm{CO}_{2}$ equivalent per unit of area during the year, was calculated according to the formula:

$$
\mathrm{e}_{\mathrm{mm}}=\mathrm{Q}_{\mathrm{mmf}} \times \mathrm{E}_{\mathrm{f}}
$$

Fuel consumption in the use of agricultural and forestry machinery $\left(\mathrm{Q}_{\mathrm{mmf}}\right)$ is expressed in volume unit per area unit per year $\left(\mathrm{dm}^{3} / \mathrm{ha}\right.$ /year). The standard coefficient of emissions from production and fuel consumption $\left(\mathrm{E}_{\mathrm{f}}\right.$ ), according to the data of BioGrace calculator (v. 4d), was used [21]. For diesel, it is $87.64 \mathrm{gCO}_{2} \mathrm{eq} / \mathrm{MJ}$.

\section{Results and Discussion}

The estimated emissions from biomass production in the farms under study ranged from $41.5 \mathrm{~kg}$ $\mathrm{CO}_{2} \mathrm{eq} / \mathrm{t}$ dry matter in the case of rye cultivation (in the farm No. 14) to $147.2 \mathrm{~kg} \mathrm{CO}$ eq/t in the case of maize cultivation (in the farm No. 15) (Table 3). The low value of emission from rye cultivation in the farm No. 14, located in Lubusz Voivodeship, is mainly the result of not using mineral fertilizers at the cultivation stage. On the other hand, the maximum GHG emission that is caused by maize cultivation in farm No. 15 is mainly the result of the applied dose of fertilizers and relatively high nitrous oxide field emission estimated in the GNOC calculator at $1.4 \mathrm{~kg} \mathrm{~N} 2 \mathrm{O}-\mathrm{N} / \mathrm{ha}$. However, it should be emphasized that the highest emissions from maize cultivation were also shown by studies for the cultivation of winter wheat, spring wheat, winter rapeseed, sugar beet, and maize in arable farm in eastern Poland, which were carried out using the GNOC calculator by Syp et al. [32]. In turn, Jarosz and Faber [33], estimating GHG emissions from wheat, maize, and rapeseed cultivation using the BioGrace (v. 4d) calculator, showed that the highest emissions from cultivation was for rapeseed, followed by wheat and maize.

The average GHG emissions from biomass production are the highest for wheat cultivation at $103.6 \mathrm{~kg} \mathrm{CO} 2 \mathrm{eq} / \mathrm{t}$. The lower average emission value was obtained for maize $\left(100.5 \mathrm{~kg} \mathrm{CO} \mathrm{CO}_{2} \mathrm{eq} / \mathrm{t}\right)$, followed by triticale $\left(95.4 \mathrm{~kg} \mathrm{CO}\right.$ eq/t) and rye $\left(72.5 \mathrm{~kg} \mathrm{CO}_{2}\right.$ eq/t) respectively (Figure 2). This sequence due to GHG emission from wheat, maize, and rye cultivation is consistent with the results of 
Rajaniemi et al. [34] and Sapkota et al. [35]. However, Tongwane et al. [36], studying GHG emissions from different crop production and management practices in South Africa, found almost $50 \%$ higher emissions from maize cultivation when compared to wheat.

Table 3. GHG emissions from cultivation of agricultural crops for biofuels $\left(\mathrm{e}_{\mathrm{ec}}\right)$.

\begin{tabular}{|c|c|c|}
\hline No. of Farms & Crop & $e_{\text {ec }}\left(\mathrm{kg} \mathrm{CO}{ }_{2}\right.$ eq/t Dry Matter $)$ \\
\hline \multirow{2}{*}{1} & wheat & 113.4 \\
\hline & triticale & 74.4 \\
\hline \multirow{2}{*}{2} & wheat & 112.4 \\
\hline & triticale & 104.5 \\
\hline 3 & maize & 77.6 \\
\hline 4 & rye & 78.1 \\
\hline 5 & triticale & 106.8 \\
\hline 6 & triticale & 108.4 \\
\hline \multirow{3}{*}{7} & wheat & 105.6 \\
\hline & triticale & 99.8 \\
\hline & maize & 76.7 \\
\hline 8 & rye & 98.0 \\
\hline 9 & triticale & 108.5 \\
\hline 10 & triticale & 79.0 \\
\hline 11 & triticale & 76.0 \\
\hline 12 & triticale & 101.4 \\
\hline \multirow{2}{*}{13} & wheat & 82.9 \\
\hline & triticale & 95.2 \\
\hline 14 & rye & 41.5 \\
\hline 15 & maize & 147.2 \\
\hline \multirow{4}{*}{ Total } & minimum & 41.5 \\
\hline & maximum & 147.2 \\
\hline & average & 94.4 \\
\hline & $\sigma$ & 21.9 \\
\hline
\end{tabular}

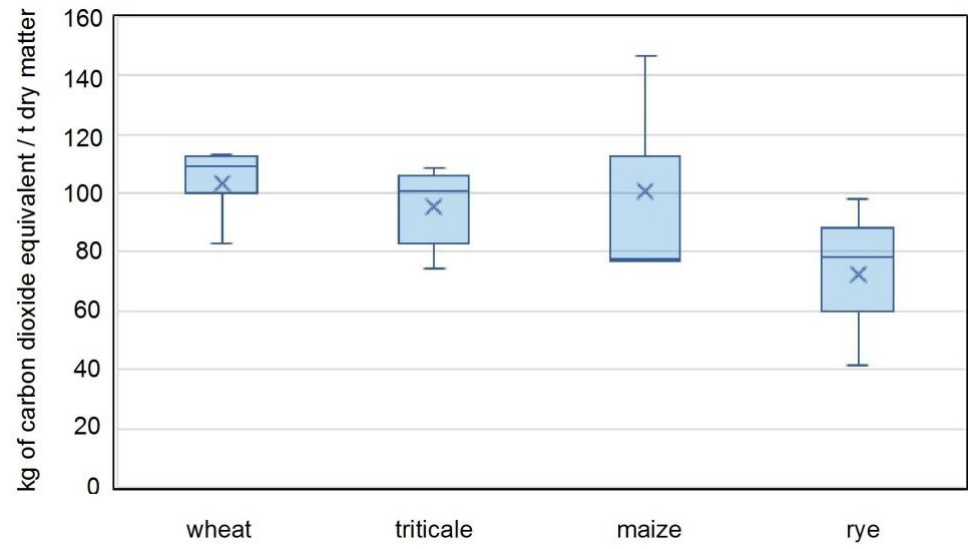

Figure 2. Boxplots presenting the range of GHG emissions from cultivation of agricultural crops for biofuels with average and median. 
The calculations show that field emissions of nitrous oxide $\left(\mathrm{e}_{\text {field }}\right)$ as well as emissions from the production and transport of fertilizers and agrochemicals $\left(\mathrm{e}_{\mathrm{chem}}\right)$ are the key components of GHG emissions from biomass production (Table 4). The dominant share of these sources in the structure of GHG emission is characteristic for all of the examined crops and amounts, on average, to $52.7 \%$ (maximum $73.5 \%$ for rye in farm No. 14 ) in the case of field emission and $37.4 \%$ (maximum $53.8 \%$ for maize in farm No. 3) in the case of emission from the production and transport of fertilizers and agrochemicals. Similarly, the results of analysis of GHG emissions in winter wheat farms, as carried out by Syp et al. [37] in south-central Poland, indicate that in total emissions the highest share was field $\mathrm{N}_{2} \mathrm{O}$ emissions (49-52\%), followed by nitrogen fertilizer (31-33\%) and diesel fuel (11-13\%). For comparison, Brock et al. [38], conducting research on GHG emissions from the production of $1 \mathrm{t}$ of wheat (in the life cycle) in Central Zone (East) New South Wales, found that $54.7 \%$ of emissions are generated on farm, of which $25.7 \%$ from fertilizers and $13.5 \%$ from combustion of diesel in tractor and harvester. There are a variety of management techniques that should conserve $\mathrm{N}$ and decrease the amount of $\mathrm{N}$ application that is needed to grow crops and limit $\mathrm{N}_{2} \mathrm{O}$ emissions. Using nitrification inhibitors is an option for decreasing fertilizer $\mathrm{N}$ use and additionally directly mitigating $\mathrm{N}_{2} \mathrm{O}$ emissions. Inhibitors may be selected for climatic conditions and the type of cropping system, as well as the type of nitrogen (solid mineral $\mathrm{N}$, mineral $\mathrm{N}$ in solution, or organic waste materials) and applied with the fertilizers [39]. Although the factors that control $\mathrm{N}_{2} \mathrm{O}$ production are known, it is impossible to predict their interaction under field conditions on the basis of the available information. These factors greatly affect the $\mathrm{N}_{2} \mathrm{O}$ emission that is generated by fertilizers. The processes of nitrification and denitritication, and the controls of the reduction of $\mathrm{N}_{2} \mathrm{O}$ to $\mathrm{N}_{2}$, have specific optimum conditions. Redox, moisture, and $\mathrm{C}$ sources change during the year and from one year to another, and the importance of the different $\mathrm{N}_{2} \mathrm{O}$ producing processes also changes as a consequence. The variability in the data is caused by a variety of factors that are related to weather and management and their interaction, such as local rainfall and temperature, timing and frequency of irrigation, history, mode and timing of fertilizer application, presence or absence of crops, type of crop, and soil management [40,41].

Table 4. The structure of GHG emissions from cultivation of agricultural crops for biofuels.

\begin{tabular}{|c|c|c|c|c|c|}
\hline \multirow{2}{*}{ No. of Farms } & \multirow{2}{*}{ Crop } & \multicolumn{4}{|c|}{ Share of Individual Emission Sources (\%) } \\
\hline & & $\mathbf{e}_{\text {seed }}$ & $\mathbf{e}_{\text {chem }}$ & $\mathbf{e}_{\text {field }}$ & $\mathbf{e}_{\mathrm{mm}}$ \\
\hline \multirow{2}{*}{1} & wheat & 4.8 & 40.3 & 53.5 & 1.4 \\
\hline & triticale & 5.7 & 36.9 & 56.4 & 1.0 \\
\hline \multirow{2}{*}{2} & wheat & 8.5 & 39.6 & 50.6 & 1.3 \\
\hline & triticale & 9.1 & 42.6 & 46.9 & 1.4 \\
\hline 3 & maize & 5.5 & 53.8 & 39.1 & 1.5 \\
\hline 4 & rye & 10.9 & 31.6 & 55.5 & 2.0 \\
\hline 5 & triticale & 5.8 & 47.8 & 45.3 & 1.1 \\
\hline 6 & triticale & 9.8 & 41.1 & 47.9 & 1.1 \\
\hline \multirow{3}{*}{7} & wheat & 6.7 & 38.3 & 53.8 & 1.2 \\
\hline & triticale & 8.5 & 38.8 & 51.0 & 1.6 \\
\hline & maize & 1.3 & 39.8 & 57.6 & 1.4 \\
\hline 8 & rye & 11.2 & 42.0 & 45.0 & 1.7 \\
\hline 9 & triticale & 12.5 & 42.6 & 43.2 & 1.7 \\
\hline 10 & triticale & 12.2 & 31.4 & 54.1 & 2.2 \\
\hline 11 & triticale & 11.3 & 24.1 & 63.0 & 1.6 \\
\hline 12 & triticale & 5.5 & 48.0 & 45.0 & 1.5 \\
\hline \multirow{2}{*}{13} & wheat & 6.4 & 32.6 & 59.9 & 1.0 \\
\hline & triticale & 8.1 & 36.0 & 54.7 & 1.2 \\
\hline 14 & rye & 22.2 & 0.8 & 73.5 & 3.4 \\
\hline 15 & maize & 1.1 & 39.2 & 58.7 & 1.0 \\
\hline \multirow{4}{*}{ Total } & minimum & 1.1 & 0.8 & 39.1 & 1.0 \\
\hline & maximum & 22.2 & 53.8 & 73.5 & 3.4 \\
\hline & average & 8.4 & 37.4 & 52.7 & 1.5 \\
\hline & $\sigma$ & 4.6 & 10.8 & 7.9 & 0.6 \\
\hline
\end{tabular}


For this reason, it is also important to use an appropriate tool to estimate the emissions from cultivation. The improvement of the accuracy of field emission estimations is of significant importance for the reduction of agricultural emissions in the full life cycle of the biofuel [42].

The studies carried out so far of other authors [26,29,43,44] have indicated that taking local environmental conditions in the GNOC calculator used in this work into account allows for a more accurate estimation of field emission of $\mathrm{N}_{2} \mathrm{O}$. It is usually lower than the emission estimated with the use of a simpler, but omitting local climatic conditions, soil, and farm management method, IPCC method at the Tier 1 level. Moreover, the application of this tool enables the development of effective climate change mitigation strategies, including the assessment of the impact of the dose and type of fertilizer, period and manner of its application, as well as the applied cultivation techniques [45]. Taking the emissions from the production and transport of fertilizers and agrochemicals into account, it should be noted that not only the dose of applied fertilizers, but also their type (manufacturer, composition, and emission factor), is important for the final GHG emission from biomass production. Therefore, it is necessary to raise farmers' awareness in this respect and increase the attention of fertilizer manufacturers to the aspect of GHG emission reduction [46]. It is necessary to analyse to what extent the existing eco-innovations in the fertilizer domain might reduce the fertilizer carbon footprint without compromising crop productivity. For example, typical mineral fertilizers were compared with so-called stabilized nitrogen fertilizers and secondary raw material fertilizers in the study of Hasler et al. [47]. Additionally, an effect of the combination of irrigation with fertilization (i.e., fertigation) was investigated. With an adopted life cycle assessment approach focusing on $\mathrm{CO}_{2}$ and $\mathrm{N}_{2} \mathrm{O}$ emission, the carbon footprints of the different fertilizer options were considered. The calculations showed that, especially the use of stabilized nitrogen fertilizer, reduced the fertilization related carbon footprint up to $13 \%$. However, the adoption of these innovations is expected to be rather limited in the near future because of higher costs or incomplete supply chain relationships. Fertilizers that were made from secondary raw materials resulted in similar carbon footprints as mineral ones, but they can help to close nutrient cycles and use by-products of other production processes [47].

The total GHG emissions from biomass production are much less affected by emissions generated during the production, storage, and transport of seeds $\left(\mathrm{e}_{\mathrm{seed}}\right)$. Its share in the structure of emissions from cultivation ranges from $1.1 \%$ for maize in farm No. 15 to $22.2 \%$ for rye in farm No. 14 , averaging $8.4 \%$. For comparison, research on the yield gaps and ecological footprints of potato production systems in Chile by Haverkort et al. [48] showed that main sources of emission (75\%) were those that were related to fertilizer production (35\%), fertilizer-induced field emission (25\%), and seed production $(15 \%)$.

Of minimum significance is the emission from the use of fuels in agricultural and forestry machines $\left(\mathrm{e}_{\mathrm{mm}}\right)$ - from $1 \%$ for triticale in farm No. 1 and wheat in farm No. 13 , to $3.4 \%$ for rye in farm No. 14 , with the average for all of the examined crops at the level of $1.5 \%$. While fossil fuel consumption is small in comparison to other terms in the agricultural GHG balance (such as nitrous oxide and ruminant methane), modeling on-farm fossil fuel consumption in response to these land management measures has a role to play in climate change mitigation strategies [49]. It should also be borne in mind that the yield level of individual plants also influences the GHG emission from biomass production. Calculations and studies of other authors $[38,50,51]$ show that lower yields cause an increase in the estimated greenhouse gas emissions as a result of the cultivation of raw materials, being expressed per dry matter unit.

\section{Conclusions}

The estimated emissions from biomass production in the examined farms vary from $41.5 \mathrm{~kg}$ $\mathrm{CO}_{2} \mathrm{eq} / \mathrm{t}$ of dry matter in the case of rye cultivation to $147.2 \mathrm{~kg} \mathrm{CO}_{2} \mathrm{eq} / \mathrm{t}$ in the case of maize cultivation. The average emissions are the highest for wheat $\left(103.6 \mathrm{~kg} \mathrm{CO}_{2} \mathrm{eq} / \mathrm{t}\right)$, slightly lower for maize $(100.5 \mathrm{~kg}$ $\left.\mathrm{CO}_{2} \mathrm{eq} / \mathrm{t}\right)$ and triticale $(95.4 \mathrm{~kg} \mathrm{CO} 2 \mathrm{eq} / \mathrm{t})$, and the lowest for rye $\left(72.5 \mathrm{~kg} \mathrm{CO}_{2} \mathrm{eq} / \mathrm{t}\right)$. 
The field emissions of nitrous oxide and emissions from the production and transport of fertilizers and agrochemicals are the key components of GHG emissions from biomass production. The dominant share of these sources in the emission structure is characteristic for all of the crops examined and amounts to $52.7 \%$ (maximum $73.5 \%$ ) and $37.4 \%$ (maximum $53.8 \%$ ), respectively. Taking local environmental conditions, such as soil texture, climate, soil organic matter, $\mathrm{pH}$, and vegetation in the GNOC calculator used in this study into account allowed for a more accurate estimation of field emission of nitrous oxide, which is important in reducing agricultural emissions in the full life cycle of biofuel. In the case of emissions connected with the use of fertilizers, not only their dose, but also their type and composition are important.

The emission generated at the stage of seed production, storage and transportation $(8.4 \%$ on average), as well as the emission from the use of fuels in agricultural and forestry machines $(1.5 \%$ on average) have much lower impact on the total GHG emission from biomass production. Crop yield also has a noticeable impact on the obtained results-its decrease causes an increase in the estimated GHG emission from biomass production.

Author Contributions: Conceptualization, P.W. and M.K.; methodology, P.W. and M.K.; formal analysis, P.W. and M.K.; investigation, P.W. and M.K.; resources, P.W. and M.K.; data curation, P.W. and M.K.; writing-original draft preparation, P.W. and M.K.; writing-review and editing, P.W. and M.K.; visualization, P.W. and M.K. All authors have read and agreed to the published version of the manuscript.

Funding: This research was funded by Department of Landscape Research and Environmental Management, University of Gdansk.

Conflicts of Interest: The authors declare no conflict of interest.

\section{References}

1. Paska, J.; Sałek, M.; Surma, T. Current status and perspectives of renewable energy sources in Poland. Renew. Sustain. Energy Rev. 2009, 13, 142-154. [CrossRef]

2. European Union. Directive (EU) 2018/2001 of the European Parliament and of the Council of 11 December 2018 on the Promotion of the Use of Energy from Renewable Sources; Official Journal of the European Union: Luxembourg, 2018.

3. Statistics Poland. Energy from Renewwable Sources in 2018; Statistics Poland: Warsaw, Poland, 2019.

4. Sulewski, P.; Majewski, E.; Was, A. The importance of agriculture in the renewable energy production in Poland and the EU. Probl. Agric. Econ. 2017, 1, 50-74.

5. Piwowar, A.; Dzikuć, M. Development of Renewable Energy Sources in the Context of Threats Resulting from Low-Altitude Emissions in Rural Areas in Poland: A Review. Energies 2019, 12, 3558. [CrossRef]

6. Igliński, B.; Piechota, G.; Buczkowski, R. Development of biomass in Polish energy sector: An overview. Clean Techn Env. Policy 2015, 17, 317-329. [CrossRef]

7. Jasiulewicz, M. The energety potential of agriculture biomass in Polish regions in the aspect of the realize national aim index at the RES 2020 year. Ann. Paaae 2014, 16, 70-76.

8. Jasiulewicz, M. Implementation of the National Indicative Target for renewable energy sources on the example of biomass in Poland and prospects of achieving this target by 2020. Rural Stud. 2016, 42, 105-112.

9. Banja, M.; Sikkema, R.; Jégard, M.; Motola, V.; Dallemand, J.F. Biomass for energy in the EU-The support framework. Energy Policy 2019, 131, 215-228. [CrossRef]

10. Błażejczyk, K. Climate and bioclimate of Poland. In Natural and Human Environment of Poland. A Geographical Overview; Degórski, M., Ed.; Polish Academy of Sciences; Institute of Geography and Spatial Organization Polish Geographical Society: Warsaw, Poland, 2006; pp. 31-48.

11. Mocek, A. (Ed.) Soil Science; Polish Scientific Publishers: Warsaw, Poland, 2015.

12. Witek, T. (Ed.) Valorisation of Polish Agricultural Production Space by Commune; Institute of Soil Science and Plant Cultivation: Pulawy, Poland, 1981.

13. Institute of Soil Science and Plant Cultivation (IUNG). Valorisation of the Agricultural Production Space; Institute of Soil Science and Plant Cultivation: Pulawy, Poland, 2007.

14. Łabaz, B.; Kabała, C. Origin, properties and classification of "black earths" in Poland. Soil Sci. Annu. 2014, $65,80-90$. 
15. Łabaz, B.; Kabała, C.; Dudek, M.; Waroszewski, J. Morphological diversity of chernozemic soils in south-western Poland. Soil Sci. Annu. 2019, 70, 211-224. [CrossRef]

16. Oil and Gas Institute-National Research Institute (IniG-PIB). Guidelines for the Determination of the Lifecycle per Unit Values of GHG Emissions for Biofuels, Bioliquids; Oil and Gas Institute-National Research Institute: Cracow, Poland, 2017.

17. European Union. Directive 98/70/EC of the European Parliament and of the Council of 13 October 1998 Relating to the Quality of Petrol and Diesel Fuels and Amending Council Directive 93/12/EEC; Official Journal of the European Union: Luxembourg, 1998.

18. European Union. Directive 2009/28/EC of the European Parliament and of the Council of 23 April 2009 on the Promotion of the Use of Energy from Renewable Sources and Amending and Subsequently Repealing Directives 2001/77/EC and 2003/30/EC; Official Journal of the European Union: Luxembourg, 2009.

19. Rogowska, D.; Berdechowski, K.; Łaczek, T. The development of the KZR INiG System-European certification scheme. Naft. -Gaz 2016, 5, 370-375. [CrossRef]

20. Intergovernmental Panel on Climate Change (IPCC). Climate Change 2013. The Physical Science Basis. Contribution of Working Group I to the Fifth Assessment Report of the Intergovernmental Panel on Climate Change; IPCC: Cambridge, UK; New York, NY, USA, 2013.

21. BioGrace. Available online: https://www.biograce.net (accessed on 17 February 2020).

22. European Commission. Joint Research Centre. GNOC—Global Nitrous Oxide Calculator. Available online: https://gnoc.jrc.ec.europa.eu (accessed on 17 February 2020).

23. European Union. Communication from the Commission on the Practical Implementation of the EU Biofuels and Bioliquids Sustainability Scheme and on Counting Rules for Biofuels (2010/C 160/02); Official Journal of the European Union: Luxembourg, 2010.

24. Amon, B.; Hutchings, N.; Vinther, F.P.; Nielsen, P.K.; Poulsen, H.D.; Kristensen, I.S.; Pietrzak, S. Analysis of Methodologies for Calculating Greenhouse Gas and ammonia Emissions and Nutrient Balances; Publications Office of the European Union: Luxembourg, 2011.

25. Köble, R. The Global Nitrous Oxide Calculator-GNOC-Online Tool Manual; European Commission, Joint Research Centre, Institute for Energy and Transport: Ispra, Italy, 2013.

26. Syp, A.; Faber, A.; Kozak, M. Assessment of $\mathrm{N}_{2} \mathrm{O}$ emissions from rapeseed cultivation in Poland by various approaches. Int. Agrophys. 2016, 30, 501-507. [CrossRef]

27. Stehfest, E.; Bouwman, A.L. $\mathrm{N}_{2} \mathrm{O}$ and $\mathrm{NO}$ emission from agricultural fields and soils under natural vegetation: Summarizing available measurement data and modeling of global annual emissions. Nutr. Cycl. Agroecosyst. 2006, 74, 207-228. [CrossRef]

28. Edwards, R.; Mulligan, D.; Giuntoli, J.; Agostini, A.; Boulamanti, A.; Koeble, R.; Marelli, L.; Moro, A.; Padella, M. Assessing GHG Default Emissions from Biofuels in EU Legislation. Review of Input Database to Calculate Default GHG Emissions, Following Expert Consultation 22-23 November 2011, JRC Scientific and Policy Reports. EUR 25595 EN; European Commission, Joint Research Centre, Institute for Energy and Transpor: Ispra, Italy, 2012.

29. Ruser, R.; Fuß, R.; Andres, M.; Hegewald, H.; Kesenheimer, K.; Köbke, S.; Räbiger, T.; Suarez Quinones, T.; Augustin, J.; Christen, O.; et al. Nitrous oxide emissions from winter oilseed rape cultivation. Agric. Ecosyst. Environ. 2017, 249, 57-69. [CrossRef]

30. Cherubini, F.; Peters, G.P.; Berntsen, T.; Strømman, A.H.; Hertwich, E. $\mathrm{CO}_{2}$ emissions from biomass combustion for bioenergy: Atmospheric decay and contribution to global warming. Gcb Bioenergy 2011, 3, 413-426. [CrossRef]

31. Brack, D. Woody Biomass for Power and Heat. Impacts on the Global Climate; The Royal Institute of International Affairs: London, UK, 2017.

32. Syp, A.; Gębka, A.; Żukiewicz, A. $\mathrm{N}_{2} \mathrm{O}$ emissions in arable farm. Ann. Paaae 2016, 18, 328-332.

33. Jarosz, Z.; Faber, A. Changes in the development of the sector of liquid biofuels. Ann. Paaae 2016, 18, 110-116.

34. Rajaniemi, M.; Mikkola, H.; Ahokas, J. Greenhouse gas emissions from oats, barley, wheat and rye production. Agron. Res. 2011, 9, 189-195.

35. Sapkota, T.B.; Aryal, J.P.; Khatri-Chhetri, A.; Shirsath, P.B.; Arumugam, P.; Stirling, C.M. Identifying high-yield low-emission pathways for the cereal production in South Asia. Mitig. Adapt. Strateg. Glob. Chang. 2018, 23, 621-641. [CrossRef] 
36. Tongwane, M.; Mdlambuzi, T.; Moeletsi, M.; Tsubo, M.; Mliswa, V.; Grootboom, L. Greenhouse gas emissions from different crop production and management practices in South Africa. Environ. Dev. 2016, 19, $23-35$. [CrossRef]

37. Syp, A.; Faber, A.; Borzecka-Walker, M.; Osuch, D. Assessment of Greenhouse Gas Emissions in Winter Wheat Farms Using Data Envelopment Analysis Approach. Pol. J. Environ. Stud. 2015, 24, 2197-2203. [CrossRef]

38. Brock, P.; Madden, P.; Schwenke, G.; Herridge, D. Greenhouse gas emissions profile for 1 tonne of wheat produced in Central Zone (East) New South Wales: A life cycle assessment approach. Crop Pasture Sci. 2012, 63, 319-329. [CrossRef]

39. Mosier, A.R.; Duxbury, J.M.; Freney, J.R.; Heinemeyer, O.; Minami, K. Nitrous Oxide Emissions from Agricultural Fields: Assessment, Measurement and Mitigation. In Progress in Nitrogen Cycling Studies; Van Cleemput, O., Hofman, G., Vermoesen, A., Eds.; Springer: Dordrecht, The Netherlands, 1996; Volume 68, pp. 95-108.

40. Bouwman, A.F. Direct emission of nitrous oxide from agricultural soils. Nutr. Cycl. Agroecosystems 1996, 46, 53-70. [CrossRef]

41. Wiśniewski, P. Assessment of nitrous oxide emissions from agricultural soils at a local level in Poland. Int. Agrophys. 2019, 33, 303-311. [CrossRef]

42. Jarosz, Z.; Faber, A. The possibility of agricultural emission limitations from corn cultivation on bioethanol. Ann. Paaae 2016, 18, 120-126.

43. Syp, A.; Faber, A. Comparison of $\mathrm{N}_{2} \mathrm{O}$ emissions from winter wheat cultivation in Poland applying IPCC (Tier 1) method and DNDC model. Ann. Paaae 2016, 18, 254-259.

44. Walter, K.; Don, A.; Fuß, R.; Kern, J.; Drewer, J.; Flessa, H. Direct nitrous oxide emissions from oilseed rape cropping-A meta-analysis. Gcb Bioenergy 2014, 7, 1260-1271. [CrossRef]

45. Syp, A.; Faber, A.; Kozak, M. Comparison of $\mathrm{N}_{2} \mathrm{O}$ emissions from winter wheat cultivation in Poland applying Tier 1 and 2 IPCC methods. Ann. Paaae 2016, 18, 254-259.

46. Rogowska, D. The assessment of the impact of factors occurring on the cultivation stage on GHG emission in the ethanol life cycle. Naft. -Gaz 2017, 2, 119-125. [CrossRef]

47. Hasler, K.; Bröring, S.; Omta, O.S.W.F.; Olfs, H.W. Eco-innovations in the German fertilizer supply chain: Impact on the carbon footprint of fertilizers. Plant Soil Environ. 2017, 63, 531-544.

48. Haverkort, A.J.; Sandaña, P.; Kalazich, J. Yield Gaps and Ecological Footprints of Potato Production Systems in Chile. Potato Res. 2014, 57, 13-31. [CrossRef]

49. Dyer, J.A.; Desjardins, R.L. The Impact of Farm Machinery Management on the Greenhouse Gas Emissions from Canadian Agriculture. J. Sustain. Agric. 2003, 22, 59-74. [CrossRef]

50. Jarosz, Z.; Księżak, J.; Faber, A. Assessment of greenhouse gas emissions in systems used in croping maize for bioethanol production. Ann. Paaae 2017, 19, 60-65. [CrossRef]

51. Skowrońska, M.; Filipek, T. Life cycle assessment of fertilizers: A review. Int. Agrophys. 2014, 28, 101-110. [CrossRef]

(C) 2020 by the authors. Licensee MDPI, Basel, Switzerland. This article is an open access article distributed under the terms and conditions of the Creative Commons Attribution (CC BY) license (http://creativecommons.org/licenses/by/4.0/). 